\title{
Dynamic Characterization of Macrobending Loss Optical Fiber-Based Load Sensor
}

\author{
Bambang Widiyatmoko ${ }^{1^{*}, \text { Mefina Y. Rofianingrum }}{ }^{2}$, Kerista Sebayang ${ }^{3}$, \\ Grecia Monalisa Manullang ${ }^{4}$ \\ 1,2 Physics Research Centre-Lembaga Ilmu Pengetahuan Indonesia LIPI, Komplek Puspiptek Gedung 442 \\ Serpong Tangerang Selatan Banten 15314, Indonesia. \\ ${ }^{3,4}$ Department of Physics, Faculty of Mathematics and Natural Science, Universitas Sumatera Utara \\ 20155, Indonesia.
}

\begin{abstract}
The weight of vehicles passing through the road greatly affects road damage, so it is necessary to have a non-stop weighing system or Weight in Motion (WIM). In this study, the dynamic characterization of the WIM sensor was carried out based on the principle of optical fiber macrobending. In this study, a single-mode step-index optical fiber was used as the sensor material and a laser diode with a power of $5 \mathrm{~mW}$ and a wavelength of $1,550 \mathrm{~nm}$ as a light source. Characterization was carried out by running over the sensor using a motor with three variations of speed, namely $10 \mathrm{~km} / \mathrm{hour}, 15 \mathrm{~km} / \mathrm{hour}$, and 20 $\mathrm{km} /$ hour. Two different conditions were also carried out, namely, the sensor was directly crushed and the sensor was reinforced in the form of a half-cylinder wooden beam. The test was carried out with three different types of sensors. From the observations, data shows that the addition of a beam can increase the accuracy of the reading as seen from the smaller the difference in the output voltage reading for the same type of sensor and vehicle speed. Besides that, there is a strengthening of the sensor resistance up to 10 times which is known from the sensor output voltage where the voltage at the addition of the beam is $1 / 10$ of the reading without the beam. This is due to an increase in the sensor area exposed to the load.
\end{abstract}

Keyword: Macrobending, Optical Fiber, Weight In Motion.

Received 5 February 2021 | Revised [19 February 2021] | Accepted [25 February 2021]

\section{Introduction}

In 1918, the government concluded that trucks were essential to road design. Today, it is known that heavy trucks cause most of the damage on the road. Truck weight regulations are strictly enforced to protect sidewalks and bridges from the effects of heavy loads to ensure the safety of all drivers and maintain traffic operations that can be managed properly and efficiently [1].

Currently, infrastructure development is one of the main focuses of the Indonesian government's performance. One of them is the percentage of road and bridge infrastructure which is the main choice of transportation in Indonesia, around $90 \%$ of the movement of national goods

\footnotetext{
*Corresponding author at: Komplek Puspiptek Gedung 442 Serpong Tangerang Selatan Banten 15314, Indonesia

E-mail address: bamb039@lipi.go.id
} 
transportation uses land routes [2]. However, in Indonesia, monitoring of truck loads is generally not done and even if there is, it still uses a static weighing method that allows for interaction between drivers and officers. Some of the methods used by the static weighing system include using load cell, piezoelectric and quartz crystals based sensors. In addition, this load cell-based vehicle weighing system is also difficult to implement as a WIM system because the sensor area is in the form of a spot so there will be a difference in the load displayed if the vehicle's wheels miss the available sensors [3].

Current technological advances can help reduce these problems. In this case, it takes a lot of systems and sensors that are used for the measurement of various physical variables. The development of fiber optic sensor technology has good advantages such as high sensitivity, resistance to electromagnetic wave interference, high temperatures, and corrosion as well as a link between the light source and the photodetector [4]. The weakness of optical fibers is the loss or loss of optical fibers caused by the effect of bending on the optical fiber. However, this study will use fiber optic loss as a load sensor to measure vehicle loads in a moving state [5]. Until now, fiber optic sensors have been widely used to monitor various environmental parameters such as position, vibration, strain, temperature, humidity, viscosity, chemicals, pressure, current, electric field and several other environmental factors [6].

In connection with this problem, optical fiber-based sensor technology seems to be an alternative solution. Weigh in Motion (WIM) is a method used for measuring vehicle loads that can be done when the vehicle is in motion which is used in vehicle traffic counting [7]. Some of the advantages of WIM technology include being more efficient and saving time, especially during busy traffic. This will support the modernization of traffic management [8]. Weigh in Motion (WIM) technology has several types of sensors that have been developed including piezoelectric sensors, bending plates, load cells, capacitive mats and optical fibers [9].

Therefore, many researchers are trying to find other types of sensors that allow replacing existing sensors with better specifications, namely by using optical fibers [9]. Optical fiber is a waveguide that can guide light which is widely used in communication systems. Another use of optical fiber is as a sensor for several physical changes such as temperature, refractive index, shift, load, etc. The aspects used as the basis for the manufacture of sensors also vary. The loss effect due to curvature is also one that can be used as a basis for making sensors. This usually uses both microbending and macrobending loss. Theoretically, an analysis of bending loss from single mode optical fibers has been carried out both in calculation and simulation [10], even the theoretical and simulation approaches have been refined by [11]. In principle, the connection between pressure and bending loss to external disturbances such as pressure [12], even to improve this aspect in implementation, improvements in production have been made. However, verification of the bending loss phenomenon, both macro and micro, is still needed to generate 
knowledge about the potential use of this effect as a load sensor. This fiber-optic-based sensor reduces mechanical construction and is more resistant to use in the tropics.

To realize this optical fiber-based WIM system, preliminary research has been carried out and reported in various writings [13-15], but in this preliminary research it can only prove the concept of a loss-based sensor. microbending loss and not being able to measure vehicles with large tonnages due to limited attenuation to direct loads to the optical fiber. Damping improvements have also been made using various types of polymers. However, with this technique there are still many obstacles, especially the uneven load on the fiber because it uses woven wire as a microbending loss generator.

Further research has been carried out with both macrobending and microbending. However, these studies can only characterize statically using a press machine so that further research is needed to determine the static characteristics of the sensor. For this reason, this research will perform a static sensor characterization using moving loads.

\section{Methods}

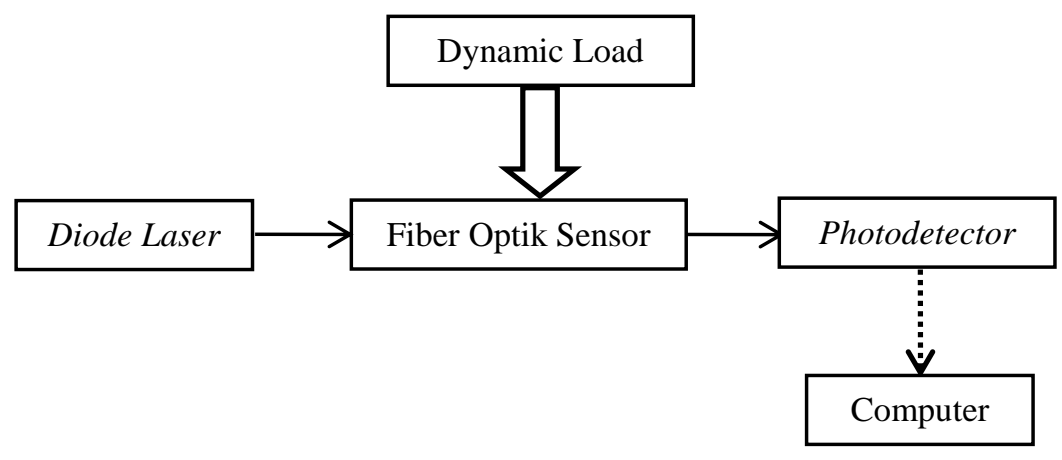

Figure 1. Experiment Scheme

In research, optical fiber sensors based on the principle of macrobending loss are designed by wrapping optical fibers on a SUNFLEX RH150 hose filled with silicon to strengthen resistance to loads. The scheme of experiment is given in Figure 1.

The light source used is a diode laser where the output has been converted into voltage (volts) using a photodetector and the magnitude of the output voltage for the axle load of the front wheels and rear wheels of the vehicle will be displayed on the computer [15].

The load sensor is the most basic and important component in the WIM system because it directly measures the force applied by the vehicle passing through the sensor [16-18]. In this study, the working principle of optical fiber sensors is based on the utilization of losses due to macrobending in optical fibers which results in changes in the intensity of light transmitted by 
optical fibers. Fiber optic sensors can be used in measuring physical parameters, namely voltage [19].

There are three types of sensors with certain configurations. Sensor 1 has a random variation of the winding distance between $0.5 \mathrm{~cm}$ to $1.5 \mathrm{~cm}$, sensor 2 has a distance between turns of $1.5 \mathrm{~cm}$ and sensor 3 has a distance of $1.5 \mathrm{~cm}$ with a diameter of $3.85 \mathrm{~cm}$ so that from the three the sensor configuration, we can find the linearity and sensitivity values of the sensors that are the best.

The data was collected by running over the sensor with a dynamic load in the form of a Supra X type motor that runs with one rider and variations in speed [20]. This is done to see differences in responses at various speeds. The flowchart is given in Figure 2.

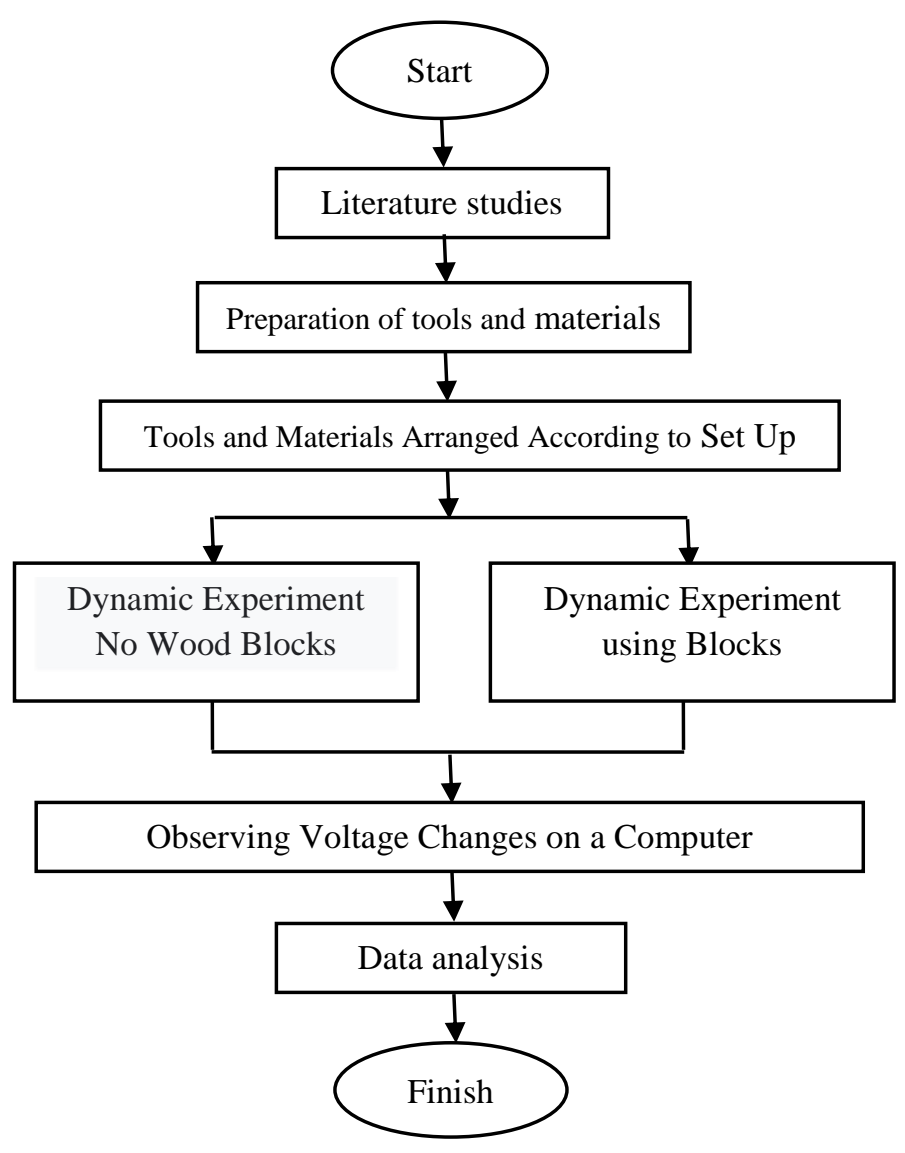

Figure 2. Flowchart of the Experiment

\section{Result and Discussion}

Dynamic test is carried out by running sensors placed in the mechanic in the form of the letter $\mathrm{V}$ with Supra X type vehicles driven by one rider with a vehicle speed, namely $10 \mathrm{~km} / \mathrm{h}, 15 \mathrm{~km} / \mathrm{h}$, $20 \mathrm{~km} / \mathrm{h}$. In the first mechanical test experiment without wooden block, fiber optic sensors will be directly run over by the motor with the area of the sensor affected by pressure equal to the width of the motor tire. In the second mechanical test experiment with the same variation in 
vehicle speed was given the addition of a simple mechanical system in the form of a $50 \mathrm{~cm}$ long half-cylinder wooden beam with the aim of providing an even load at a wider area of the sensor to strengthen the sensor from more load. This strengthening will be matched with the results of the experiment and compare the data when without the addition of wooden block (Figure 3 ) and when added wooden block (Figure 4).

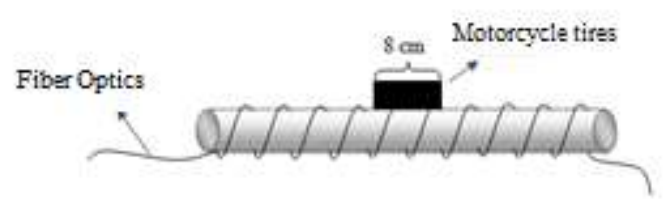

Figure 3. Sensor without wooden block

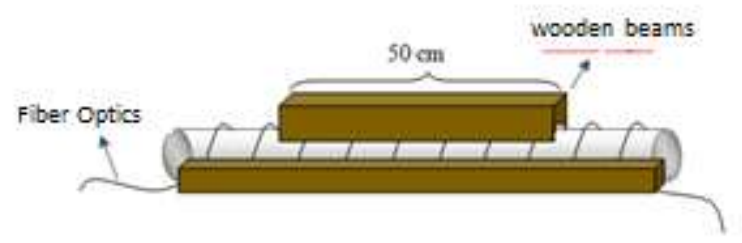

Figure 4. Sensors with The Addition of Wooden block

\subsection{Comparison of Average Stress for Each Speed}

Table 1. Comparison of Average Voltages of Both Mechanical Test Sensors 1

\begin{tabular}{ccc}
\hline \multirow{2}{*}{ Vehicle Speed $(\mathrm{km} / \mathrm{h})$} & \multicolumn{2}{c}{ Average Voltage on Sensor (volt) } \\
\cline { 2 - 3 } & No Wood Blocks & Using Wood Blocks \\
\hline 10 & 4,7395 & 0,464 \\
15 & 5,17 & 0,619 \\
20 & 5,676 & 0,698 \\
\hline
\end{tabular}

Table 2. Comparison of the Average Voltage of the Two Sensor Mechanical Tests 2

\begin{tabular}{ccc}
\hline \multirow{2}{*}{ Vehicle Speed $(\mathrm{km} / \mathrm{h})$} & \multicolumn{2}{c}{ Average Voltage on Sensor (volt) } \\
\cline { 2 - 3 } & No Wood Blocks & Using Wood Blocks \\
\hline 10 & 3,16 & 0,6575 \\
15 & 3,116 & 1,255 \\
20 & 2,0025 & 1,335 \\
\hline
\end{tabular}

Table 3. Comparison of Average Voltages of Both Mechanical Test Sensors 3

\begin{tabular}{ccc}
\hline \multirow{2}{*}{ Vehicle Speed $(\mathrm{km} / \mathrm{h})$} & \multicolumn{2}{c}{ Average Voltage on Sensor (volt) } \\
\cline { 2 - 3 } & No Wood Blocks & Using Wood Blocks \\
\hline 10 & 4,584 & 0,3925 \\
15 & 4,822 & 0,472 \\
20 & 4,78 & 0,63 \\
\hline
\end{tabular}

In Tables 1,2, and 3 with speed variations of $10 \mathrm{~km} / \mathrm{h}, 15 \mathrm{~km} / \mathrm{h}$, and $20 \mathrm{~km} / \mathrm{h}$, the average voltage value on sensors without wood Block is greater than sensors using wood blocks. 


\subsection{Sensitivity and Linearity of Fiber Optic Sensors For Each Treatment}

Table 4. Sensitivity/gradient values for each sensor

\begin{tabular}{cl}
\hline Types of treatment on fiber optic sensors & \multicolumn{1}{c}{ Gradient } \\
\hline Sensor 1 (without Wood Blocks) & $\mathrm{m}=0,0965$ \\
Sensor 2 (without Wood Blocks) & $\mathrm{m}=-0,011575$ \\
Sensor 3 (without Wood Blocks) & $\mathrm{m}=-0,0196$ \\
Sensor 1 Using Wood Blocks) & $\mathrm{m}=0,0234$ \\
Sensor 2 (Using Wood Blocks) & $\mathrm{m}=0,06775$ \\
Sensor 3 (Using Wood Blocks) & $\mathrm{m}=0,02375$ \\
\hline
\end{tabular}

Table 4 shows the sensitivity of sensors without wooden block is smaller compared to sensors that use wood blocks. Sensors 2 and 3 without wood blocks have the most weakening (power losses).

Table 5. Linearity values for each sensor

\begin{tabular}{cc}
\hline Types of treatment on fiber optic sensors & Linearity \\
\hline Sensor 1 (without Wood Blocks) & $\mathrm{R}^{2}=0,997$ \\
Sensor 2 (without Wood Blocks) & $\mathrm{R}^{2}=0,778$ \\
Sensor 3 (without Wood Blocks) & $\mathrm{R}^{2}=0,595$ \\
Sensor 1 Using Wood Blocks) & $\mathrm{R}^{2}=0,960$ \\
Sensor 2 (Using Wood Blocks) & $\mathrm{R}^{2}=0,837$ \\
Sensor 3 (Using Wood Blocks) & $\mathrm{R}^{2}=0,964$ \\
\hline
\end{tabular}

From the graph between loss and vehicle speed can be obtained linearity results for each fiber optic sensor. If the linearity value is close to or equal to 1 , both variables have a linearity relationship. Based on Table 5 linearity above the best linearity value is in sensors using wood blocks.

\subsection{Sensor Durability Gain Analysis}

In the condition without beam means that the motor wheel is directly exposed to the sensor, where the area of the sensor affected by the load is an area of $1 / 2$ selinder sensor with a length of $8 \mathrm{~cm}$ (width of motor tires) and the radius of the sensor is $1.5 \mathrm{~cm}$ wide $37.68 \mathrm{~cm}^{2}$. As for the addition of cylinder beams with a radius of $5 \mathrm{~cm}$ and a length of $50 \mathrm{~cm}$, the area of the sensor affected by the load becomes $392.5 \mathrm{~cm}^{2}$. The area will increase 10 times wider. This means that the voltage generated when using the beam will be smaller than when not using the beam compared to its area. 


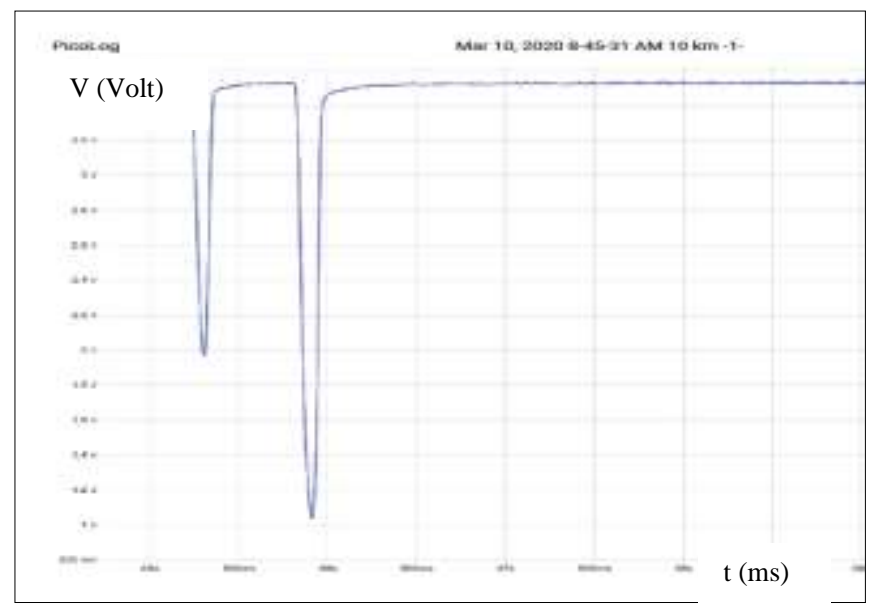

Figure 5. Graph of sensor voltage change $1 \mathrm{~V}=10 \mathrm{~km} / \mathrm{h}$ without blocks

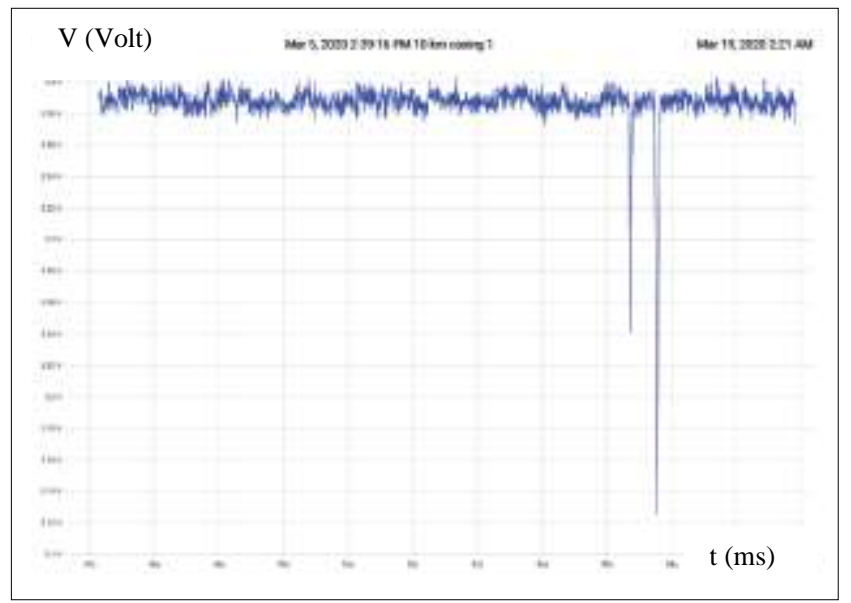

Figure 6. Graph of sensor voltage change $1 \mathrm{~V}=10 \mathrm{~km} / \mathrm{h}$ using blocks

By taking the example of one front tire only at a speed of $10 \mathrm{~km} / \mathrm{h}$ it is seen that the current voltage does not use a wood blocks of $2.19 \mathrm{~V}$ (Figure 5) and when using a blocks of $0.17 \mathrm{~V}$ (Figure 6) or only 0.1 voltage when without a blocks. This means that if the output voltage is the same as when without blocks then the load held will be 10 times heavier according to the ratio of the area of the sensor affected by the load. From the data above, the strengthening of sensor load power can be done by expanding the area of the sensor affected by the load. This condition will require different calibration at the time of static test.

By comparing the value of the voltage difference when without using blocks by using a block there is a strengthening of the pressure strength of the sensor when adding blocks or increasing the area of the sensor affected by the load, where the gain $(\mathrm{G})$ can be calculated as equation (1).

$$
G=\left[V_{o}-V_{d}\right] \text { without block } /\left[V_{o}-V_{d}\right] \text { using block }
$$

From the calculation obtained reinforcement between 5 to 10 times. This difference in value is due to the imperfect mechanical system used in this experiment. 


\section{Conclusion}

The average voltage change in the sensor uses wooden block for a speed of $10 \mathrm{~km} / \mathrm{h}$ on the 1 sensor of 0.464 Volts, sensor 2 of 0.6575 Volts and sensor 3 of 0.3925 Volts. For a speed of 15 $\mathrm{km} / \mathrm{h}$ on the 1 sensor of 0.619 Volts, sensor 2 of 1,255 Volts and sensor 3 of 0.472 Volts. For a speed of $20 \mathrm{~km} / \mathrm{h}$ on the 1 sensor of 0.698 Volts, sensor 2 of 1,335 Volts, and sensor 3 of 0.63 Volts. In addition, the addition of the area of the sensor affected by the load using wooden block can increase the resistance to the imposed load where the sensor can withstand the load between 5 to 10 times. There are also sensors that have the highest sensitivity and linearity in sensor 1 without using wooden block, sensor 2 using wooden block, and sensor 3 using wooden block. This is due to the imperfect sensor mechanism.

\section{REFERENCES}

[1] T. Kwon and B. Aryal, Development of a PC-Based Eight-Channel WIM System, Minnesota: Minnesota Department of Transportation, 2007.

[2] W. Nugraha and G. Sukmara, "Uji Coba Model Fisik Sistem Bridge Weigh in Motion Sederhana Pada Jembatan Gelagar Baja Komposit (Trial Model Of A Simple Bridge Weigh in Motion System on Steel Girder Composite Bridge)", Jurnal Jalan-Jembatan, vol. 35, no. 1, pp. 1-15, 2018.

[3] C.R. Farrar, W. E. Baker, T. M. Bell, K. M. Cone, T. W. Darling, T. A. Duffey, A. Eklund, and A. Migliori, Dynamic characterization and damage detection in the I-40 bridge over the Rio Grande (No. LA-12767-MS). Los Alamos National Lab., NM (United States), 1994.

[4] R. K. Ula, H. Y. Regina, and D. Hanto, "Sensor Beban Berbasis Optik dengan Micro bending Fiber Optik Tipe MMSI FG050LGA", Seminar Nasional Jurusan Fisika Fmipa Um 2016, 2016.

[5] Y. Zheng, Z. W. Zhu, W. Xiao, D. M. Gu, and Q. X. Deng, "Investigation of a quasidistributed displacement sensor using the macro-bending loss of an optical fiber", Optical Fiber Technology, vol. 55, p.102140, 2020.

[6] K. A. Fidanboylu and H. S. Efendioglu, "Fiber optic sensors and their applications", In 5th International Advanced Technologies Symposium (IATS'09), vol. 6, pp. 2-3, 2009, May.

[7] T. Septiana, and Z. Zaini, "Perancangan dan Implementasi Sistem Monitoring Beban dan Kecepatan Kendaraan Menggunakan Teknologi Weigh in Motion", Jurnal Nasional Teknik Elektro, vol. 7, no.1, pp.60-68, 2018.

[8] A. Setiono, D. Hanto, and B. Widiyatmoko, "Investigasi sensor serat optik untuk aplikasi sistem pengukuran berat beban berjalan (Weight in motion system)", TELAAH Jurnal Ilmu Pengetahuan dan Teknologi, vol. 31, no.1, pp.81-86, 2013.

[9] W. Hidayat, Analisis Serat Optik Multimode Inficore 300 Terbengkokkan untuk Aplikasi Penimbangan Beban Kendaraan Berjalan (Weigh In Motion), Doctoral dissertation, UNS, Sebelas Maret University, 2015.

[10] D. Marcuse, "Curvature loss formula for optical fibers", JOSA, vol. 66, no. 3, pp.216-220, 1976.

[11] T. Volotinen, L. Stensland, and A. Bjork, "The 11b () Method, a way to investigate the bending and bend sensitivityof single modefibers'", OFMC, vol. 91, pp.20-23, 1991.

[12] R. B. Malla, A. Sen, and N. W. Garrick, "A special fiber optic sensor for measuring wheel loads of vehicles on highways", Sensors, vol. 8, no. 4, pp.2551-2568, 2008.

[13] Setiono, D. Hanto, B. Widiyatmoko, dan B. Waluyo, "Kajian Penerapan Konsep Impuls untuk Menghitung Berat Kendaraan Berjalan Menggunakan Sensor Serat Optik", In Prosiding Seminar Nasional Fisika, Semarang 8 Juni 2013, pp. 3-6, 2013.

[14] R. K. Ula, D. Hanto, dan B. Widiyatmoko, "Analisis Perbandingan Penggunaan LASER 
dan LED sebagai Sumber Cahaya pada Sensor Berat Berbasis Optik", In Prosiding Seminar Nasional Fisika 2015, pp. 323-326, 2015.

[15] W. Widodo, D. Hanto, and W. Waslaluddin, "Uji Coba Dan Analisis Sensor Serat Optik Untuk Weight In Motion (Wim) Pada Replika Kendaraan Statis Dan Dinamis", Fibusi (Jurnal Online Fisika), vol. 3, no. 3, 2015.

[16] I. Al-Qadi, H. Wang, Y. Ouyang, K. Grimmelsman, and J. Purdy, LTBP program's literature review on weigh-in-motion systems, United States Department of Transportation, Federal Highway Administration, 2016.

[17] J. Gajda, R. Sroka, M. Stencel, T. Zeglen, P. Piwowar, P. Burnos, and Z. Marszalek, "Design and accuracy assessment of the multi-sensor weigh-in-motion system", IEEE, pp. 1036-1041, 2015, May.

[18] D. Dan, L. Ge, and X. Yan, "Identification of moving loads based on the information fusion of weigh-in-motion system and multiple camera machine vision", Measurement, vol. 144, pp.155-166, 2019.

[19] M. Yunianto, M. Ahmad, and I. Zuhdi, "Desain Alat Ukur Rugi-Rugi Akibat Macrobending pada Multi-Mode Optical Fiber Berbasis Personal Computer", Indonesian Journal of Applied Physics, vol.2, no.2, pp.138-145, 2012.

[20] P. Szary and A. Maher, Implementation of Weigh In Motion (WIM) System, Washington D. C: Federal Highway Administration U.S. Department of Transportation, 14, 2009. 